\title{
Secondary school science teacher education and quality control in Korea based on the teacher qualifications and the teacher employment test in Korea
}

\author{
Youngsun Kwak®
}

Correspondence: kwak@knue.ac.kr Department of Earth Science

Education, Korea National University of Education, Cheongju, Republic of Korea

\begin{abstract}
The purpose of this article is to examine the quality management of the secondary school science teachers in Korea. To improve the quality of teachers, it takes a coherent policy effort over the entire teaching career including pre-service teacher training, a quality control of teacher employment, and in-service teachers' professional development. The focus of this article is to explore ways to improve science teacher training and quality control, centering on the teacher employment test of secondary school teachers in Korea. In this context, the curriculum of the science teacher training colleges, which is based on the science teacher professional standards and knowledge base, and the specifics of the teacher employment test are examined. Science teacher education in Korea faces many challenges due to the inconsistency between the supply and demand of science teachers, the decrease in the number of students, the implementation of high school credit system, and so on. Based on the analysis results, ways to improve secondary science teacher education and quality control system are suggested Major suggestions include requirement of completion of basic subjects related to adjacent subjects in science subject areas to solve the out-of-field teaching, necessity of introducing multiple teacher certificates to cope with challenges of reduced class hours due to fewer students, and necessity of reinforcing practice-oriented education in teacher training process to bridge the gap between theory and practice for beginning teachers.
\end{abstract}

Keywords: Secondary school science, Science teacher education, Teacher employment test, Teacher knowledge base

초록

이 논문의 목적은 한국의 중등학교 과학 교사의 질 관리 방안을 탐색하는 것이 다. 교사의 수준을 향상시키기 위해서는 예비 교사교육을 포함하여 교직 경력 전반에 걸친 일관된 정책적 노력을 필요로 한다. 이 논문의 초점은 한국의 중 등학교 과학 교사 임용시험을 중심으로, 과학교사 양성과 질 관리에 대한 개선 방안을 탐색하려는 것이다. 이러한 목적을 달성하기 위해, 과학 교사 전문성 기 준 및 지식기반에 근거한 과학교사 양성대학의 교육과정, 교사임용시험의 세 부 사항 등을 점검하였다. 한국의 과학교사교육은 과학교사 수요와 공급의 불 일치, 학령 학생 수의 감소, 고등학교 학점제 시행 등으로 인해 많은 도전에 직 (Continued on next page) 
(Continued from previous page)

면하고 있다. 분석 결과를 바탕으로 중등 과학 교사교육 및 질 관리 시스템을 개선할 수 있는 방안을 제안하였다. 주요 개선 방안으로는 상치교사 문제, 즉 물리학, 화학, 생명과학 또는 지구과학 교사자격증을 가지고 중학교에 발령을 받아서 중학교 과학 과목을 가르치거나 고등학교에 발령을 받아서 통합과학 과목을 가르쳐야 하는 문제점을 해결하기 위해 교사 양성과정에서 전공을 막 론하고 기본이수과목에 일반과학 및 실험, 즉 일반 물리학화학/생물학/지구과 학 및 실험을 모두 이수하게 하는 방안, 학생 수 감소에 따른 과학과 선택과목 수업 시수 감소 문제를 해결하기 위해 복수자격증 제도를 도입하는 방안, 초임 교사들이 학교현장에서 겪는 이론과 실천의 괴리 문제를 해결하기 위해 교사 양성과정에서 실천중심의 교육을 강화하는 방안 등을 제안하였다.

\section{Introduction}

The Republic of Korea ${ }^{1}$ has been famous for its students' outstanding achievement of science and mathematics in international exams for the last two decades. According to the results, in particular, of the Trends in International Mathematics and Science Study (TIMSS) and the Programme for International Assessment (PISA), Korea has been one of the top performing countries in science and math (Mullis et al. 2016; OECD 2016). High student achievement on international assessments in science and mathematics has been associated with excellence in teacher education and professional development (Ku et al. 2017; Sang et al. 2016). That is, the quality of teachers is discussed as the most important factor in deciding teacher accountability and quality education in the light of student assessment results. According to in-depth analyses of the relationship between teacher quality and Korean students' performance on international tests like TIMSS and PISA, the higher the qualification level of science teachers and quality teacher readiness, the higher the student achievement (Chung et al. 2014; Kim et al. 2016; Kim and Kim 2015; Yi et al. 2011). With a high level of teacher readiness and the screening process with the teacher employment test in Korea helps prospective teachers develop essential knowledge and teaching skills (KICE 2016). As a result, the greatest concern has been to identify and maintain competent teachers in all areas and grades in order to provide equal educational opportunities for all students (Allen 2003). To improve the quality of teachers, it takes a coherent policy effort over the entire teaching career including pre-service teacher training programs, a quality control in teacher employment, teachers' professional development, and so on.

This study focuses on teacher quality management in Korea of the big picture of the whole teacher policy, from the training of science teachers to the selection and placement of teachers as well as the ongoing professional development of in-service teachers. In this context, therefore, before examining the teacher employment test, we will examine the composition of the teacher training curriculum based on the science teacher qualification criteria. This is because the teacher qualification standard, and the composition area of the teacher training curriculum are used as criteria for the secondary teacher employment test. In the selection and placement of teachers, including science teachers, the link between training, qualification, and appointment is important.

${ }^{1}$ Hereafter referred to as Korea, and citizens are referred to as Korean. The Republic of Korea is commonly referred to as South Korea. 
Secondary science teacher training and education are affected by the revision of secondary school science curriculum. In particular, due to the recent expansion of the high school selective-based curriculum and the credit system, various policy pressures have been applied in secondary teacher education including science. In this context, we will suggest ways to improve teacher training and reeducation of secondary school science teachers.

\section{Teacher preparation requirements and standards}

In Korea, elementary schoolteachers are classroom teachers teaching all subject areas, and secondary schoolteachers are subject teachers teaching one's own specialized subject area such as general science for middle schools and physics for high schools. Teacher preparation for secondary school teachers in Korea is offered by teachers colleges as well as by non-specializing institutions including teacher education programs and graduate schools of education (Kim 2005; Wang et al. 2016). Secondary school science teachers are trained at the university's colleges of education (teachers colleges, hereafter), departments of education in general universities ${ }^{2}$, and graduate schools of education. The graduate schools of education, which are intended for the advanced training of in-service teachers, provide teaching certificate programs including sciences for those graduates of related natural sciences majors or career changers.

Even with diversity in the institutions and programs of teacher preparation, the educational curricula of teacher preparation for secondary school subject teachers are standardized due to the teacher employment test. Table 1 shows different types of training institutions of secondary school science teachers. Each institution or program has the freshmen quota of 10 30 students depending on each institution's capacity. Teacher training institutions for secondary school science teachers include 10 national or public teachers colleges and 9 private teachers colleges, as well as numerous graduate schools of education.

Secondary school science teachers' certification fields include integrated science (i.e., general science for middle school), physics, chemistry, biology, and earth science, which are consistent with secondary school science subject areas. Among the secondary science teachers in Korea, biology teachers are the most demanded. We, therefore, illustrated graduate schools of education that produce biology teachers. Graduate schools of education for secondary school biology teachers include 18 national/public, and 14 graduate schools for the year 2018.

In order to enter teachers colleges, applicants need to have educational attainment at least equivalent to that of a high school diploma. Since the economic crisis of the late 1990s in Korea, secondary as well as primary teaching jobs have become one of the most wanted occupations because of job stability, which resulted in top performers enter teachers colleges.

The Ministry of education encourages the applicants' aptitude for teaching and their personality be assessed in the entrance examination considering the uniqueness and the professionalism of the teaching profession. To meet the needs of the era of

\footnotetext{
${ }^{2}$ Secondary school teachers are also produced by departments of education in general universities, and there are 619 national or public general universities and 119 private universities (Kim 2005). Among these departments of education in general universities, a few of them produce graduates with secondary school science teaching certificate. In this article, therefore, we exclude these graduates.
} 
Table 1 Teacher training institutions for secondary school science teachers, 2018

\begin{tabular}{llll}
\hline Types of institution & Number of institution & Total \\
\cline { 2 - 4 } & National/Public & Private & \\
\hline Teachers College & 10 & 9 & 19 \\
Graduate School of Education (biology) & 18 & 14 & 32 \\
Total & 28 & 23 & 51 \\
\hline
\end{tabular}

Source: MOE (2017)

globalization and the information age, the curricula of teachers colleges have emphasized pedagogical content knowledge, information management ability including computer use, skills of counseling students, and so on (Hwang et al. 2014; Park 2013).

Upon graduation, graduates of teacher training institutions are entitled to receive the teaching certificate, and there exists no graduation examination administered at national level. Certified science teachers get employed either the national/public or private schools. The Ministry of Education is responsible for the hiring of national/ public school teachers, and basic matters such as procedures and methods of the employment test are specified by law. However, superintendents of the 17 Metropolitan and Provincial Offices of Education are delegated by the Education Minster to exercise the authority to employ national/public school teachers (Educational Civil Servant Employment Act, Article number 3) (Kim 2005). To be employed by national/public schools, a certified teacher must pass the teacher employment test administered by the 17 Metropolitan and Provincial Offices of Education.

Since the teacher employment test consists mainly of a paper-and-pencil test covering pedagogical and subject matter knowledge, critics often argue that it is of limited value in evaluating the prospective teachers' teaching skills or their aptitude for teaching (Kim et al. 2005). Meanwhile, in the case of private schools, the methods and procedures for teacher employment are determined by individual school foundations. According to regulations for private school teachers, acquisition of the teaching certificate follows the same regulation for the teachers of national/ public schools, but the matters pertaining to teacher employment is decided by individual schools.

\section{Curricula for secondary school science teacher education}

The current certification subjects of the secondary school science teacher along with related departments in teachers colleges are displayed in Table 2.

Regarding the change of the subjects of science teacher qualifications, prior to 1997, there were four majors of science subjects, and general science courses were required to complete for every science teacher qualification.

\section{Professional knowledge base of secondary school science teachers}

The curriculum of the teacher training program is based on the knowledge base that constitutes the professionalism of teachers. Shulman's study $(1987,1988)$ was designed to identify the knowledge base that defines teachers as professions, that is, their own specialized knowledge base. Shulman (1987) proposes a variety of components of the teacher knowledge base, arguing that there is a series of knowledge bases for teaching 
Table 2 Certification subjects and related schools (departments)

\begin{tabular}{ll}
\hline Certification subjects & Related schools (departments) \\
\hline Integrated Science & $\begin{array}{l}\text { Science education, Physics education, Chemistry education, Biology education, } \\
\text { Earth science education, Integrated science education major and related schools } \\
\text { (majors, departments) }\end{array}$ \\
Physics & $\begin{array}{l}\text { Science education, Physics education, Physics and related schools (majors, departments) } \\
\text { Chemistry } \\
\text { Science education, Chemistry education, Chemistry and related schools (majors, } \\
\text { departments) }\end{array}$ \\
Earth Science & $\begin{array}{l}\text { Science education, Biology education, Biology and related schools (majors, departments) } \\
\text { Separtments) }\end{array}$ \\
\hline
\end{tabular}

Sources: MOE (2018, p. 239)

that makes teachers professional. Since Shulman (1987), various domains have been proposed to support the teacher's knowledge base, including science teaching (Choe et al. 2011).

- Science subject matter knowledge

- General pedagogical knowledge

- Science Curriculum knowledge

- Science Pedagogical Content Knowledge (PCK)

- Knowledge of science learners and their characteristics

- Knowledge of the educational context

- Knowledge of the goal, process, values, philosophy and historical foundation of education

Of these teaching knowledge categories, Shulman (1987) emphasized the importance of pedagogical content knowledge (PCK). It defines a unique system of knowledge about teaching, which is knowledge about organizing and applying specific curriculum content and teaching methods to the learner's characteristics. In other words, it is a mixture of curriculum content and pedagogy, the teacher's understanding of how specific topics, problems, or issues are organized and presented, and translated and presented for lessons according to learners' various interests and abilities. PCK is, therefore, a category that separates the understandings of content experts and teachers.

\section{Science teacher preparation curriculum}

The curriculum of the teacher training program is a core element of the teacher training program as an intentional system of what knowledge teachers need to know, skills to be able to develop, and ways to develop them. However, due to the lack of consensus on the professional knowledge and skills of the teacher, i.e., the knowledge base of the teaching profession, the curriculum of teacher training programs differs from country to country (Kim 2005; Lee and Kwak 2017). In Korea, the teacher training curriculum focuses on the qualifications and competencies of teachers, and this teacher training curriculum is linked to the teacher employment test in Korea. In other words, the curriculum of the teacher training program will be organized according to the Teacher Expertise Criteria, which is an agreed criterion on what basic qualifications and competencies teachers should have. There is, still, curricular variance among various teachers 
colleges. For example, the total credit hours for graduation vary from 140 to 150 depending on the institution provides secondary school science teacher certification along with general science certification as minor subject.

The curriculum of the secondary school science teacher training program is guided by the Enforcement Regulation Number 12 of the Teacher Certification Authorization Act [Act No. 26710], which specifies a certain number of subject matter and pedagogy courses, which acts as a minimum level of standardization to help maintain uniformity among various curricula of teachers colleges that produce secondary school science teachers. The curriculum of the secondary school science teacher training program consists of science subject matter, science pedagogical content knowledge (PCK), and pedagogy courses, and there has been much debate about the adequacy of the ratio of the number of credits in each component area. As a result of this controversy, which is a kind of zero-sum game, the total number of basic credits in the teacher training curriculum is gradually increasing (Hwang et al. 2014; Lee and Kwak 2017; Wang et al. 2016).

Prospective teachers who satisfactorily meet the graduation requirements specified by the Teacher Certification Authorization Act receive a teaching certificate. The teaching certificate is conferred by the Minister of Education through an authorization procedure without examination (Wang et al. 2016). It means that the certificates are conferred automatically upon graduation. They specify the school level for which the teacher is eligible to teach as well as major and minor subjects he or she is authorized to teach. Pre-service teachers can obtain teaching certificates without taking any exam if they have taken the required courses that follow the Teacher Certification Authorization Act (Act No. 26710) and its detailed regulations. The certificate can be attained by completing the specified number of teacher training courses in nationally approved teacher training institutions. The Ministry of Education, furthermore, regularly evaluates teacher education institutions based on certain criteria, and provides differential financial supports for each institution based on the evaluation results.

Table 3 shows criteria for passing the no-test exam for science teacher candidates. The curriculum of teachers colleges is composed based on the criteria for passing the teacher qualification no-test exam. To obtain science teacher qualification through the no-test examination, students must earn credits through the formal curriculum of the teacher training program. The teacher training curriculum, including secondary science teachers, is divided into liberal arts, pedagogy, and major courses. Teachers colleges

Table 3 Criteria for passing the no-test exam for science teacher candidates

\begin{tabular}{lll}
\hline Areas & Since 2013 & \\
\hline Major areas & 50 credits or more & Grade Average score of \\
& -12 credits (6 courses) or more of Basic Required & at least 75/100 in majors \\
& Courses & \\
& -8 credits (3 courses) or more of science education & \\
& courses (content specific pedagogy) & Grade Average score of at \\
Pedagogy areas & 22 credits or more & least $80 / 100$ in pedagogy \\
& -12 credits (6 courses) or more of Teaching Theory & \\
Teaching Aptitude and & -6 credits (3 courses) or more of Teaching Literacy & \\
Personality Test & 2 or more eligibility determinations & \\
First Aid and CPR Practice & Receive more than twice & \\
\hline
\end{tabular}

Sources: Regulations for Teacher Certification Authorization Act (MOE 2015) 
offer a four-year programs like general universities and the total credit hours required to acquire teaching certificate is normally 140 , including over 50 credit hours of major courses and over 22 credit hours of general pedagogy courses, with small differences among colleges.

Major areas consist of subject matter areas, as well as content specific pedagogy area, that is, science education courses or pedagogical content knowledge (PCK) areas. In a usual teachers colleges, students are required to take over 50 credit hours of major areas, with the average GPA of at least 75/100, to receive teaching certificate. Required courses in major areas include at least 12 credits (6 courses) or more of Basic Required Courses in subject matter areas, and at least 8 credits ( 3 courses) or more of science education courses.

Regarding pedagogy courses for secondary school science teaching certificates, candidates should acquire over 22 credit hours of pedagogy courses, with the average GPA of at least 80/100, to receive teaching certificate. Pedagogy courses consist of Teaching Theory, Teaching Literacy, and Teaching Practice courses. Teaching theory courses include Introduction to Education, History and Philosophy of Education, Curriculum, Educational Evaluation, Educational Psychology, etc. Teaching literacy courses include Education for Special Needs, Theories about Prevention of School Violence, and so on, which are designed to meet current social needs.

\section{Science subject matter}

Table 4 shows the basic courses (fields) in each of the secondary science subjects listed in the current Teacher Qualifications Manual (MOE 2018).

Major issues raised in the science contents course of the science teacher training curriculum are as follows:

First, there is less distinction between science content subjects offered in teachers colleges, and those offered in the natural science colleges (e.g., physics, chemistry, life sciences, astronomy, etc.). In the curriculum of teachers colleges, science content is necessary for the development of professionalism of preservice teachers. Although it is

Table 4 Basic courses (fields) by secondary science subjects

\begin{tabular}{ll}
\hline Subject & Basic courses (Fields) \\
\hline Integrated Science & (1) Integrated Science Education (or Science Education) \\
& (2) General Physics and Experiments, Electromagnetism, Modern Physics \\
& (3) General Chemistry \& Experiments, Inorganic Chemistry, Organic Chemistry \\
& (4) General Biology \& Experiment, Cytology, Molecular Biology \\
(5) General Earth Sciences and Experiments, Geology, Atmospheric Sciences \\
Physics education (or science education), mechanics, quantum mechanics, \\
Physics \\
electromagnetics, thermal and statistical physics, wave and optics, computational \\
physics, modern physics, physical education experiment \\
Chemistry Education (or Science Education), Physical Chemistry, Physical Chemistry \\
Chemistry & Inorganic Chemistry Experiment, Analytical Chemistry, Analytical Chemistry Experiment \\
& Life science education (or science education), cytology, embryology, plant physiology, \\
Biology & animal physiology, genetics, taxonomy, ecology, molecular biology, microbiology, \\
biochemistry & Earth Science Education (or Science Education), Geology, Astronomy, Atmospheric \\
Earth Science & Sciences, Oceanography, Geophysics, Earth Environmental Sciences, Natural Disasters \\
and Energy \\
Resources
\end{tabular}


important for preservice teachers to develop their knowledge of science subject field themselves, the subject matter knowledge that preservice teachers need should be premised on the application to secondary schools (Lee and Kwak 2017). Therefore, in constructing the science contents curriculum of teachers colleges, it is necessary to thoroughly examine whether the detailed subjects that make up the science contents are necessary for the secondary education field, and whether the contents are appropriate in view of the secondary school curriculum. In other words, considering the original purpose of the teachers colleges, the reflection and improvement of the contents and weight of scientific contents are required.

Second, the field of science content should cover the main areas of secondary school science curriculum. In the curriculum of natural science colleges, the purpose of the course is to selectively take the specialized subjects. However, the teacher training curriculum of teachers colleges should organize a science subject system that comprehensively cover major contents of the subject rather than the specialized subject system. In addition, subjects in the science content field of teachers colleges need to be periodically reorganized to reflect the revision of the secondary school curriculum. For example, the newly introduced 'Integrated Science' in high school in the 2015 revised curriculum has led to the incorporation of science content subjects related to integrated science at the teachers colleges to provide comprehensive knowledge of the basic contents of the high school integrated science curriculum.

Third, it is necessary to secure a close connection between content knowledge and content specific pedagogy (i.e., science PCK). Science content knowledge is difficult to separate from content specific pedagogy, or science PCK. The ultimate goal of science content knowledge and science PCK is to strengthen the major expertise of the teacher. Secondary science teachers who require in-depth knowledge of their major field need practical skills to integrate science content knowledge and content-specific pedagogy (Choe et al. 2011). It is, therefore, important to secure a link between science content and science education, such as giving specific examples of what science education knowledge and methodology is required when teaching specific science content.

\section{Science pedagogical content knowledge}

Science education, or science-specific pedagogy deals with the format and process of interaction between teachers and students with the science curriculum (Park 2013). Courses in science education include Science Education, Science Textbook Research and Teaching, Scientific Logic and Essay, Science Curriculum, Science Teaching \& Learning, and Science Assessment. The major issues raised in the science education course of the science teacher training curriculum are as follows:

First, the connection between science education and science contents should be secured. The science education courses in the teacher training course are to strengthen the content-specific teaching ability. There is an inseparable relationship between science content and science education courses of teachers colleges. It is, therefore, necessary to organize and operate science education courses with related science content in mind. Furthermore, by strengthening the linkage between science content and science education, it will be possible to secure the unique curriculum identity and expertise of teachers colleges (Lee and Kwak 2017). 
Second, content-specific pedagogy should strengthen the connection with general pedagogy courses. General pedagogy deals with general education theory, while content-specific pedagogy or science education deals with science-specific education theory centering on science subject. Therefore, it is necessary to provide a curriculum by linking the two in order to cultivate in-depth professionalism of preservice teachers. For example, a science education course called science teaching method should be designed science-specific contents in connection with general teaching method to provide prospective teachers with science PCK.

In addition, the lack of linkage between science education subjects and secondary school science curriculum, and the lack of linkage between experiments and practice areas required at the secondary school level should be improved. (Kim et al. 2010; Kim et al. 2015).

So far, we have examined the curriculum of science teacher training programs. The science teacher qualification criteria and the curriculum areas of the teacher training curriculum are again used as the criteria for the secondary teacher employment test.

\section{Science teacher employment test}

The teachers of national/public schools in Korea are selected via an open, competitive employment test, so called Teacher Employment Test (TET) administered by each Metropolitan and Provincial Office of Education since 1991 to eliminate the discrimination between national and private universities, Prior to 1991, graduates of national/ public teachers colleges were assigned to national/public secondary schools for compulsory service because they attended college with relatively cheaper tuition for scholarships than other colleges.

Since its first implementation in 1991, the secondary teacher employment test has undergone several changes, and since 2014, it has been changed to the current twostage test. Table 5 shows the current secondary teacher employment test system.

The TET for public schools consists of two stages. The first test is a written exam, and consists of test on pedagogy (20\%) and the major areas (80\%). Major areas consist of science content knowledge, and science PCK, which should cover the basic courses (fields) in each of the secondary science subjects listed in the Teacher Qualifications Manual. The second test consists of 'Writing teaching and learning plans', 'Class demonstration in front of examiners', 'In-depth interview about teaching aptitude', and

Table 5 Current secondary school teacher employment test system

\begin{tabular}{lll}
\hline Test stage & Test subject (Score) & Specifics \\
\hline First test & General pedagogical knowledge (20 points) & 1 item (essay test) \\
& Major A \& B exam (80 points) & $\begin{array}{l}\text { Subject matter knowledge \& Science PCK } \\
\text { (Short Answer, Constructive response, \& } \\
\text { essay items) }\end{array}$ \\
Second test & Writing teaching and learning plans (10 points) & 1 item (essay test) \\
& Class demonstration (20 points) & class demonstration with a given lesson topic \\
& In-depth interview about teaching aptitude & 4 items (oral exam) \\
& (40 points) & \\
& Science experiment (30 points) & Depending on the Metropolitan and Provincial \\
& & Office of Education, implementation, method, \\
& score assignment, etc. are differ.
\end{tabular}


Science lab experiment. Depending on the Metropolitan and Provincial Office of Education, implementation, method, score assignment, exam time of the second test, etc. are differ.

The TET is very demanding and competitive, and for some science subject the competition rate is 20 to 1 for some Metropolitan and Provincial Offices of Education. The competition rate varies depending on districts, and teacher candidates prefer Metropolitan to rural areas.

Various problems and issues have been raised in relation to the secondary teacher employment test such as limitations in assessing the teacher candidate's teaching performance, TET-driven curriculum operation of teachers colleges, deterioration of preservice teachers' interest and devotion to college education, problems of quality level of paper-based examination, lack of linkage with the teacher training process, and so on (Seo et al. 2015; KICE 2016).

Based on the results of diagnosing the characteristics and problems of Korean teacher policy, the OECD recommended that unit schools and communities need to be empowered to intervene in teacher selection in order to recruit teachers that meet the needs and characteristics of the school (Kim et al. 2005). Therefore, it is necessary to strengthen the cooperation and responsibility of the school and the community, from teacher training to recruitment, and to devise a plan to reflect the results of the teacher training process in the teacher recruitment.

\section{Conclusions and implications}

The quality of science teachers and science education are surrounded and determined by a complex ecosystem of education. In the light of student assessment results, teacher quality is the most important factor in determining teacher accountability and quality of education. As a result, the greatest concern has been to identify and maintain competent teachers in all areas and grades in order to provide equal educational opportunities for all students (Allen 2003). In light of these policy demands, the main topic of teacher education is to cultivate, select, and retain talented people, from teacher training and teacher employment to teacher reeducation.

The focus of this article is to explore ways to improve science teacher training and quality control, focusing on the employment test of secondary school science teachers in Korea. In this context, the curriculum of the science teachers colleges, which is based on the science teacher professional standards and knowledge base, and the subjects of the teacher employment test are examined. Based on the findings, ways to improve secondary science teacher education in the context of linking secondary science teacher training, science teacher's professional knowledge base, and employment test are as follows:

\section{Requirement of completion of basic subjects related to adjacent subjects in science subject areas}

Since the Secondary Teachers' employment test has not selected candidates with Integrated Science qualifications since 2013, it is no longer possible to take the secondary Teacher Employment Test for those with Integrated Science certification at teachers colleges. Therefore, the number of students who take a double major 
in Integrated Science in teachers colleges has decreased, while a single major with a single subject certificate (physics, chemistry, biology, or earth science) has increased (Kwak et al. 2017).

Particularly, secondary school science teachers who have received a single subject certificate (physics, chemistry, biology, or earth science) after 2000, have few expertise in other science fields other than their own major. In other words, because they did not take any other science courses other than their major in the teacher training course, they are limited in teaching high school Integrated Science as well as middle school Science subjects. In the case of the Integrated Science of the 2015 revised curriculum, the performance standards are organized around the core concepts that cross-cut the science subject areas, which requires science teachers' expertise in other science fields other than their major.

Science teachers who pass the employment test are randomly assigned to a middle school or a high school. That is, some science teachers who have passed the employment test in physics, chemistry, biology, or earth science majors have been assigned to middle schools after the new appointment, which results in out-of-field teaching for these middle school science teachers. For this reason, more out-of-field teaching occurs in middle school than high school science classes. Approximately $30 \%$ of the middle school teachers teaching science are out-of-field, while there are $16 \%$ at the high school level (Kim 2005).

In order to solve this problem, science teachers should be trained with a single major along with general science minor as before 2000 (KICE 2016; Lee and Kwak 2017). In this case, as in 2000, science teacher certification is issued in the form of integrated science / physics, integrated science / chemistry), integrated science / biology, integrated science / earth science. For example, in the case of physics teachers, they will receive their certifications in the form of integrated science / physics) after completing courses of 'General (Physics / Chemistry / Biology / Earth Sciences) and Experiment' as basic required courses to acquire teacher qualifications. This will solve the problem of teachers when they are appointed as middle school science teachers or when they teach high school integrated science after passing the employment test (KICE 2016; Lee and Kwak 2017). Teachers who were assigned middle schools with a degree in a single discipline and a single subject certificate are called out-of-field or misaligned teachers and they have difficulty with teaching general science course (KICE 2016; Kwak et al. 2017). Compared with teachers graduated with double majors, it is challenging for these outof-field teachers to teach general science in more integrative ways (Kwak and Shin 2018; Shin and Kwak 2019). This problem also occurs when high school science teachers with a single subject certificate teach Integrated Science course in a high school (Kwak et al. 2017; Shin and Kwak 2019). Since Integrated Science in the high school is organized by core concepts that crosscuts all science disciplines including physics, chemistry, biology, and earth science, these teachers with a single major were reluctant to teach convergent contents or contents other than one's own major (Kwak and Shin 2018; Shin and Kwak 2019).

In addition, it is necessary to reorganize the teacher training curriculum to reflect the revision trend of the secondary school science curriculum (Kwak et al. 2017). As integrated science or convergence science has been emphasized in the high school science curriculum in Korea, the curriculum as well as PCKs of the science teacher training 
programs should be revised to deal with integrated or converged trend of the secondary school science curriculum.

\section{Necessity of introducing multiple teacher certificates}

Science teacher education in Korea faces many challenges due to the inconsistency between the supply and demand of science teachers, the decrease in the number of students, the implementation of high school credit system, the activation of STEM or STEAM education and so on (Kim 2005; Kwak et al. 2017).

Recent research on teacher demand and supply revealed there would be an oversupply of secondary as well as elementary teachers starting the year 2011 due to a decrease of student population caused by low fertility rates (Kim et al. 2006). According to the National Center for Educational Statistics, the school-age population per year, which was about 670,000 in 2014, will decrease to about 430,000 by 2023, 10 years later (KESS 2019). The demand for teachers, therefore, is expected to decrease as the school-age population decreases.

Another important reason why out-of-field teaching occurs can be found in the recent change in Korea's educational policy adopting a new national curriculum that emphasizes school autonomy and student choice, so called high school credit system. At some schools, some high school elective subjects have disappeared as 11th and 12th graders have chosen not to enroll in those courses. Since Korean law secures the employment status of public school teachers, so they cannot be dismissed, even when their subjects are no longer taught.

It is, therefore, to secure the flexibility of teacher placement through revitalization of multiple majors and minors to cope with the changed educational environment, such as strengthening the choice of subjects for high school students, increasing the number of small schools, decreasing the school age population, and developing integrated courses (Hwang et al. 2014; Kim et al. 2016). In other words, plural majors and plural qualification systems for adjacent disciplines where teachers can teach various subjects should be revitalized.

\section{Necessity of reinforcing practice-oriented education in teacher training process}

Under current teacher employment circumstances in which new teachers are required to teach in the classroom immediately upon their employment without an induction period, novice teachers could not face the reality of classroom teaching with their lack of teaching practice offered during the teacher training. There should be measures to overcome the gap between theory and practice and resolve the lack of practical professionalism of novice teachers, such as providing intensive and high-quality teaching practicum to pre-service teachers, adoption of a probationary period, improving teacher preparation institution to the level equivalent to graduate school, etc. (Hwang et al. 2014; Kim 2005; Kim et al. 2016).

In conclusion, it is important to remember that the link between teacher training, qualification, and employment is critical with the selection and placement of teachers, including science teachers. The selection of good science teachers is difficult to achieve by improving the teacher employment test alone, and should be organically linked to the teacher training and qualification stages. Teacher professionalism requires 
continuous growth, not one-time cultivation, so it needs to be approached in light of lifelong education. The teacher professionalism is not equipped with all of them with the graduating from the teacher training program, but through the practice and learning at school. In particular, the pedagogical content knowledge or content-specific pedagogy is an area to be developed throughout the teaching career.

\begin{abstract}
Abbreviations
OECD: Organization for Economic Cooperation and Development; PCK: Pedagogical content knowledge; STEAM: Integrated science, technology, engineering, arts, and mathematics education; STEM: Science, technology, engineering, and mathematics; TC: The university's college of education; TET: Teacher employment test
\end{abstract}

\title{
Acknowledgements
}

Not applicable.

\section{Author's contributions}

YK reviewed and wrote the paper. The author read and approved the final manuscript.

\section{Author's information}

Youngsun Kwak is a professor at Korea National University of Education (KNUE), South Korea. Before she joined KNUE in 2018, she was a senior researcher at Korea Institute for Curriculum and Evaluation, which is in charge of national matriculation exam, national level curriculum development, teacher employment test, etc. Her research centers on science teacher education and teachers' practical knowledge such as science PCK, and phenomenological research on science classes. She published papers that address connections between theory and practice of science classroom teaching, scientific argumentation, and teachers' epistemic beliefs on science teaching. Her recent projects include competency-based science curriculum development, and science teacher professionalism in light of PCK. She directed research and evaluation of 2015 revised Integrated Science curriculum. Currently, she is the editor-in-chief of a journal, Journal of the Korean Association for Science Education (KASE).

\section{Funding}

Not applicable.

\section{Availability of data and materials}

Not applicable.

Ethics approval and consent to participate

Not applicable.

\section{Consent for publication}

The authors agree that this article will be published in the APSE journal.

\section{Competing interests}

The author declares that she has no competing interests.

Received: 29 August 2019 Accepted: 13 November 2019

Published online: 06 December 2019

\section{References}

Allen, M. (2003). Eight questions on teacher preparation. Denver: Education Commission of the States (ECS).

Choe, S., Kwak, Y., \& Noh, E. (2011). Study on teaching \& learning and teacher education for enhancement of core competency of learners: Focused on middle school Korean language, mathematics, and science subjects (Research Report RRI 2011-1). Seoul: KICE Retrieved September, 29, 2019 from http://www.kice.re.kr/resrchBoard/view.do?seq=19209\&s=kice\&m=030101.

Chung, J. Y., Lee, H., \& Kim, S. (2014). A hierarchical analysis of the factors influencing on student achievement - using the teacher and student factors of TIMSS 2011. The Journal of Korean Teacher Education, 31(2), 53-75.

Hwang, K., Park, S., Yoon, G., Lee, S., \& Choi, E. (2014). Research on revising teacher training curriculum and no-test teacher qualification standards. Korea: Ministry of Incheon and Metropolitan Office of Education.

Kim, E., Han, Y., Kim, H., \& Kim, E. (2006). The supply and demand of elementary and secondary teachers in the midst of change of school education. Seoul: Korean Educational Development Institute (KEDI). Retrieved September, 29, 2019 from https:/www.kedi.re.kr/khome/main/research/selectPubForm.do

Kim, E., Jeon, J., \& Lee, J. (2016). Improvement of curriculum area for pre-service teacher training. Seoul: Korea Foundation for the Advancement of Science \& Creativity.

Kim, E., Park, S., \& Lee, T. (2005). The OECD review on Korean teacher policy: A critical analysis. The Journal of Korean Education, 32(2), 297-319.

Kim, E.-G. (2005). The quality and qualifications of the teaching force in the Republic of Korea. In R. M. Ingersoll (Ed.), A comparative study of teacher preparation and qualifications in six nations. Washington, DC: U.S. Government Printing Office.

Kim, S., Lee, S., Shin, J., Kim, J., Yoo, J., Lee, K., Hong, H., Kang, E., Kwon, J., Kim, E., Kim, J., Kim, H., Lee, I., \& Chung, T. (2015). A study on site suitability of the secondary school teacher education curriculum focusing on science and math subject. Asian Journal of Education, 16(4), 1-30. 
Kim, Y., \& Kim, N. (2015). Exploration of student and school factors influencing on academic achievement. Korean Journal of Educational Research, 53(3), 31-60.

Kim, Y. M., Park, J. W., Park, J. S., Lee, H. N., \& Kim, Y. S. (2010). Science teachers' perceptions and needs for courses in science education subjects for science teacher preparation program in Korea. Journal of the Korean Association for Science Education, 30(6), 785-798.

Korean Education Statistics Service [KESS] (2019). The school-age population per year. Retrieved August 23, 2019 from https://kess.kedi.re.kr/index.

Korean Institute for Curriculum and Evaluation [KICE]. (2016). Improvement of evaluation system for selection of candidates for elementary and secondary teachers (II): Development of Evaluation System (Research Report RRE 2016-3). Seoul: KICE Retrieved September, 29, 2019 from http://www.kice.re.kr/resrchBoard/list.do?cate=0\&m=030101\&s=kice.

Ku, J., Cho, S., Lee, S., Park, H., \& Ku, N. W. (2017). OECD Programme for International Students Assessment: An in-depth analysis of PISA 2015 results (Research Report RRE 2017-9). Seoul: Korean Institute for Curriculum and Evaluation.

Kwak, Y., Lee, J., \& Lee, Y. (2017). Ways to improve in-service science teachers' expertise with the introduction of 'integrated science' in the 2015 revised curriculum. Journal of the Korean Association for Science Education, 37(2), 263-271.

Kwak, Y., \& Shin, Y. (2018). Analysis of enacted curriculum through classroom observation of integrated science teaching in 2015 revised curriculum. Journal of the Korean Association for Science Education, 39(3), 379-388.

Lee, Y., \& Kwak, Y. (2017). Secondary science teacher training and appointment test in Korea, Korea Science Education Content Cooperative Science Education Monograph Series No. 19. Gyeonggi: Kyoyookbook.

MOE. (2015). Regulations for teacher certification authorization act. Korea: Korea Ministry of Education.

MOE (2017). Teacher training institutions in 2017. Retrieved August 23, 2019 from https://www.moe.go.kr/boardCnts/view. do? boardID=327\&boardSeq=72604\&lev=0\&searchType=S\&status $Y \mathrm{~N}=\mathrm{C} \& p a g e=1 \& \mathrm{~s}=$ moe\&m=0305\&opType=N .

MOE. (2018). 2018 teacher qualification examination handbook. Korea: Korea Ministry of Education.

Mullis, I. V. S., Martin, M. O., Foy, P., \& Hooper, M. (2016). TIMSS 2015 international results in Mathematics. Retrieved November 23, 2017 from http://timssandpirls.bc.edu/timss2015/international-results/.

OECD (2016). PISA 2015 results in focus. Retrieved November 23, 2017 from http://www.oecd.org/pisa/pisa-2015-results-infocus.pdf

Park, B. (2013). Reflections and future directions on content specific pedagogy in Korean teacher training program. In Proceedings of the 2013 spring conference of Korean Teacher Education Association (Vol. 63, pp. 122-123).

Sang, K., Kwak, Y., Park, J. H., \& Park, S. (2016). The Trends in International Mathematics and Science Study (TIMSS): Findings from TIMSS 2015 for Korea. (Research Report RRE 2012-4-3). Seoul: Korean Institute for Curriculum and Evaluation.

Seo, J., Imm, C., Lee, Y., Jeon, H., Kim, H., Cho, B., Park, D., \& Seo, Y. (2015). Study on improving evaluation system for selecting candidates for elementary and secondary teachers (I): Analysis of current evaluation system (Research Report RRE 2015-4). Seoul: Korean Institute for Curriculum and Evaluation.

Shin, Y., \& Kwak, Y. (2019). Analysis of realities of organization and implementation of Integrated Science of the 2015 revised curriculum. Journal of Science Education, 43(1), 64-78.

Shulman, L. S. (1987). Knowledge and teaching: foundations of the new reform. Harvard Educational Review, 57(1), 1-22.

Shulman, L. S. (1988). The dangers of dichotomous thinking in education. In P. P. Grimett \& G. L. Erickson (Eds.), Reflection in teacher education (pp. 31-38). New York: Columbia University. Teacher College Press.

Wang, L., Cheung, D., Chiu, M.-H., Ogawa, M., \& Park, Y.-S. (2016). Pre-service education of high school science teachers. In H.S. Lin, J. K. Gilbert, \& C.-J. Lien (Eds.), Science education research and practice in East Asia: Trends and perspectives (pp. 273302). Taipei: Higher Educational Publishing.

Yi, H. S., Kim, S., Song, M., Kim, J., \& Yang, S. K. (2011). Structural equation models of student achievement: School contextual and instructional differences in the development of reading, math, and English construct. Journal of Educational Evaluation, 24(2), 317-344.

\section{Publisher's Note}

Springer Nature remains neutral with regard to jurisdictional claims in published maps and institutional affiliations.

\section{Submit your manuscript to a SpringerOpen ${ }^{\circ}$ journal and benefit from:}

- Convenient online submission

- Rigorous peer review

- Open access: articles freely available online

- High visibility within the field

- Retaining the copyright to your article

Submit your next manuscript at $\boldsymbol{\nabla}$ springeropen.com 